\title{
Determinants of Premarital Sex Behavior: Application of Theory of Planned Behavior and Social Cognitive Theory
}

\author{
Nur Laili Qomariah'), Eti Poncorini Pamungkasari²), Uki Retno Budihastuti3) \\ ${ }^{1)}$ Masters Program in Public Health, Universitas Sebelas Maret \\ 2)Faculty of Medicine, Universitas Sebelas Maret \\ 3)Department of Obstetrics and Gynecology, Dr. Moewardi Hospital, Surakarta
}

\section{ABSTRACT}

Background: Health problems in adolescents are among the most important problems in the human life cycle, especially reproductive and sexual problems. Actively conducted premarital sex behavior poses a risk to teenage pregnancy and transmission of sexually transmitted diseases. This study aims to analyze the theory of planned behavior and social cognitive theory on the determinants of premarital sex behavior in adolescents.

Subjects and Method: This was a crosssectional study design. The study was conducted at 25 high schools/vocational high schools in Gresik, East Java, from September to October 2020. A sampling of 200 adolescents used stratified random sampling and simple random sampling. The dependent variable was premarital sex behavior. The independent variables were the intention, attitude, subjective norms, peer support, family intimacy, and self-efficacy. The data were collected by using a questionnaire. Data were analyzed using multiple logistic regression with Stata 13.

Results: Premarital sexual behavior increased with strong intention $(b=1.06 ; 95 \% \mathrm{CI}=0.15$ to 1.98; $\mathrm{p}=0.015)$, positive attitude $(\mathrm{b}=1.22 ; 95 \%$ $\mathrm{CI}=0.38$ to $2.13 ; \mathrm{p}=0.009$ ), subjective norms supportive $(b=1.09 ; 95 \% \mathrm{CI}=0.14$ to $2.04 ; \mathrm{p}=$ 0.024), and strong peer support $(\mathrm{b}=1.37 ; 95 \%$ $\mathrm{CI}=0.44$ to $2.30 ; \mathrm{p}=0.004)$. Premarital sexual behavior decreased with strong family intimacy $(b=-1.32 ; 95 \% \mathrm{CI}=-2.23$ to $-0.40 ; \mathrm{p}=0.005)$ and strong self-efficacy for abstinence $(b=$ -1.03; 95\% CI $=-2.23$ to $-1.93 ; \mathrm{p}=0.025)$. There was an effect at the school level on premarital sex behavior with ICC 24.6\%.

Conclusion: Premarital sexual behavior increases with strong intentions, positive attitudes, supportive subjective norms, and strong peer support. Premarital sexual behavior decreases with strong family intimacy and strong abstinence self-efficacy. There is an effect at the school level on premarital sexual behavior.

Keywords: premarital sex behavior, theory of planned behavior, social cognitive theory, adolescents.

\section{Correspondence:}

Nur Laili Qomariah. Masters Program in Public Health, Universitas Sebelas Maret. Jl. Ir. Sutami 36A, Surakarta 57126. Email: lailiqomar@gmail.com. Mobile: +6281234190160.

\section{Cite this as:}

Qomariah NL, Pamungkasari EP, Uki Retno Budihastuti UR (2020). Determinants of Premarital Sex Behavior: Application of Theory of Planned Behavior and Social Cognitive Theory. J Health Promote Behav. 05(04): 272-283. https://doi.org/10.26911/thejhpb.2020.05.04.05.

cc) (i) (2) Journal of Health Promotion and Behavioris licensed under a Creative Commons Journal of Health Promotion and Behavioris licensed under a Creative
Attribution-NonCommercial-ShareAlike 4.o International License.

\section{BACKGROUND}

Health problems in adolescents are among the most important problems in the human life cycle, especially reproductive and sexual problems. One of them is unwanted pregnancy and unsafe abortion. Globally, the main causes of death in female adolescents aged 15-19 are complications from pregnancy and childbirth. About $11 \%$ of all births in the world are carried out by teenage girls aged 15-19 years, and most of these births are in developing countries. In 
developing countries, as many as 20,000 girls under the age of 18 give birth every day. This number reaches 7.3 million births per year. $95 \%$ of the births of adolescents aged 15-19 years occur in low-and middleincome countries (WHO, 2018).

The results of basic health research in 2018 reported that there were 2,867 adolescents aged 15-19 years who were pregnant and who were pregnant in the year of data collection. This figure continues to increase from year to year (Ministry of Health of the Republic of Indonesia, 2018). A report from a preliminary study conducted at the Office of the Ministry of Religion of Gresik Regency, in 2017 recorded that 25 male adolescents under 19 years of age were married. As many as 30 females under 19 years of age were married. Whereas in 2018, the number of teenage marriages has increased, it was found that there were 40 male teenage marriages under 19 years of age and as many as 37 marriages of girls under 19 years of age.

During adolescence, there are significant physical and sexual changes so that sexual attraction also develops. Rapid physical changes and hormonal changes are triggers for adolescent health problems due to the emergence of sexual motivation that makes adolescents vulnerable to diseases and reproductive health problems (Kespro), teenage pregnancy with all its consequences, namely premarital sex, abortion, sexually transmitted diseases, HIV-AIDS and narcotics (Margaretha, 2012).

Theory of Planned Behavior provides substantially more detailed information about the determinants of behavior in a person's behavior, normative, and belief control. This theory does not determine where the belief comes from but also shows several other possible factors that influence a person's beliefs, such as personality and life values, including demographic variables (education, age, gender, and income) and exposure to media and other sources. These factors are expected to influence intention and behavior indirectly (Ajzen, 2011).

Meanwhile, Social Cognitive Theory has unique characteristics that lie in the social influence and social strengthening that occurs from outside (externally) and within (internally). SCT shows the unique way each individual acquires and maintains a behavior while considering the influence of the social environment in which the individual performs the behavior. This study analyzes the determinants of premarital sex behavior in adolescents associated with the Theory of Planned Behavior (TPB) and Social Cognitive Theory (SCT).

\section{SUBJECTS AND METHOD}

\section{Study Design}

This type of study was an analytic observational method with a cross-sectional approach. The study was carried out in Gresik, East Java, from September to October 2020.

\section{Populationand Sample}

This study's population was adolescents aged 15-18 years in 25 Senior High School/Vocational High School in Gresik Regency. The number of samples of 200 research subjects consisting of 8 students taken from 25 schools. Sampling was done using stratified random sampling and simple random sampling.

\section{Study Variables}

The dependent variable was premarital sex behavior. The independent variables were the intention, attitude, subjective norms, peer support, family intimacy and selfefficacy.

\section{OperationalDefinition of Variables}

Intention was the level of certainty about the practice of behavior. In this case, there was a tendency for adolescents' actions or desires to support or not engage in risky 
premarital sexual behavior. Continuous data scale, for data analysis, is changed to a dichotomy with the criteria $0=$ weak $(<2)$, $1=$ strong $(\geq 2)$.

Attitude was a response, judgment, or expression of adolescents, shown in the form of beliefs, feelings, or actions towards premarital sex behavior. Continuous data scale, for data analysis, was converted into a dichotomy with the criteria $0=$ negative $(<2), 1=$ positive $(\geq 2)$.

Subjective norms were the interpretations of each adolescent towards normative and social effects. In this case, adolescents felt the effect of support or not to engage in premarital sexual behavior in the community where they live. The continuous data scale, for data analysis, was changed to a dichotomy with the criteria $\mathrm{O}=$ not supportive $(<4), 1=$ supporting $(\geq 4)$.

Peer support was support from friends that can affect whether or not to have premarital sexual behavior. The continuous data scale, for data analysis, was changed to a dichotomy with the criteria $0=$ weak $(<7)$, $1=$ strong $(\geq 7)$.

Family intimacy was the closeness between adolescents and two or more family members (who are joined by blood, marital relations, or adoption and live in a household). In this case, it looked at the frequency of family members' involvement with each other in everyday life. The continuous data scale, for data analysis, was changed to a dichotomy with the criteria $\mathrm{O}=$ weak $(<10), 1=$ strong $(\geq 10)$.

Self-efficacy was an individual's belief in taking certain health actions; in this case, adolescents' belief to control themselves so as not to engage in risky premarital sexual behavior. The continuous data scale, for data analysis, was changed to a dichotomy with the criteria $0=$ weak $(<13), 1=$ strong $(\geq 13)$.
Premarital sex behavior was sexual activity, which included kissing, touching sensitive body parts, hugging, masturbation, oral sex, and having sex without a legal marriage bond. Continuous data scale, for data analysis, was changed to a dichotomy with the criteria $\mathrm{O}=$ no premarital sex behavior $(<0), 1=$ premarital sex behavior $(\geq 0)$.

School was a strata level based on school discipline.

\section{Data Analysis}

Univariate analysis was used to see the frequency distribution and percentage of characteristics of study subjects. Bivariate analysis was used to determine the correlation between the dependent and independent variables using the chi-square test. Multivariate analysis used logistic regression analysis through a multilevel approach with the Stata13 program to determine the effect of level 2 (school) on premarital sex behavior.

\section{Research Ethic}

Research ethics included a submission sheet, anonymity, confidentiality, and ethical eligibility. This study's ethical feasibility came from the Health Research Ethics Committee of Dr. Moewardi Surakarta with the number 1271 / XI / HREC / 2020.

\section{Sample Characteristics}

The characteristics of the sample in this study can be seen in Table 1 . Table 1 shows that the study subjects' characteristics based on the highest gender were male, amounting to 112 people (56\%) and female by 88 people (44\%).

\section{Univariate analysis}

The descriptive statistical test results were continuous data in the form of variables of age, intention, attitude, norms, subjective, peer support, family intimacy, and selfefficacy. 
Qomariah et al./ Determinants of Premarital Sex Behavior

Tabel 1.Characteristics of Study Subjects based on sex

\begin{tabular}{lcc}
\hline \multicolumn{1}{c}{ Sample characteristics } & n & \% \\
\hline Sex & & \\
Female & 88 & $44 \%$ \\
Male & 112 & $56 \%$ \\
\hline
\end{tabular}

Table 2.Univariate Analysis (Continuous Data)

\begin{tabular}{lccccc}
\hline Variable & n & Mean & SD & Min. & Maks. \\
\hline Age (years) & 200 & 16.57 & 0.91 & 15 & 18 \\
Intention & 200 & 1.99 & 1.78 & 0 & 7 \\
Attitude & 200 & 2.07 & 1.80 & 0 & 8 \\
Norm & 200 & 3.52 & 1.11 & 2 & 7 \\
Peers & 200 & 6.99 & 1.59 & 4 & 12 \\
Family Intimacy & 200 & 9.51 & 2.51 & 4 & 14 \\
Self-efficacy to not to do & 200 & 12.64 & 1.53 & 8 & 14 \\
Premarital Sex Behavior & 200 & 0.67 & 0.74 & 0 & 3 \\
\hline
\end{tabular}

Table 3. Univariate analysis (dichotomous data)

\begin{tabular}{llcc}
\hline \multicolumn{1}{c}{ Variable } & Criteria & Frequency (n) & $\begin{array}{c}\text { Percentage } \\
\text { (\%) }\end{array}$ \\
\hline Intention & Weak & 99 & 49.5 \\
& Strong & 101 & 50.5 \\
Attitude & Negative & 94 & 47 \\
Subjective norms & Positive & 106 & 53 \\
& Unsupportive & 100 & 50 \\
Peer Support & Supports & 100 & 50 \\
& Weak & 92 & 46 \\
Family intimacy & Strong & 108 & 54 \\
\multirow{2}{*}{ Self-efficacy to not to do } & Weak & 111 & 55.5 \\
\multirow{3}{*}{ Premarital sexual behavior } & Strong & 89 & 44.5 \\
& Lemah & 99 & 49.5 \\
& Kuat & 101 & 50.5 \\
& Yes & 98 & 49 \\
\hline
\end{tabular}

Table 2 explains that the mean score of intention was $1.99($ mean $=1.99 ; \mathrm{SD}=1.78)$ with the lowest value 0 and the highest 7 . The attitude variable had an average value of 2.07 (mean= 2.07; $\mathrm{SD}=1.80$ ) with the lowest value. $\mathrm{o}$ and highest 8 . The subjective norm variable had an average value of 3.52 (mean $=3.52 ; \mathrm{SD}=1.11)$ with the lowest score of 2 and the highest 7. The peer support variable had an average value of 6.99 (mean= 6.99; $\mathrm{SD}=1.59$ ), with the lowest score was four and the highest was 12. The family intimacy variable had an average value of 9.51 (mean $=9.51 ; \mathrm{SD}=$ 2.51) with the lowest value was 4 , and the highest was 12. The self-efficacy variable for not doing had an average value of 12.64 (mean= 12.64; $\mathrm{SD}=1.53$ ) with the lowest score of 8 and the highest of 14 . The premarital sex behavior variable had an average value of $0.67($ mean $=0.67 ; \mathrm{SD}=0.74)$ with the lowest score of 0 , and the highest was 3 .

The characteristics of 200 adolescents who were the study subjects are shown in Table 3 with the following explanation: 
most adolescents had strong intentions with 101 (50.5\%) while adolescents with weak intentions were 99 (49.5\%). Adolescents with negative attitudes were 94 (47\%), while adolescents with positive attitudes were more than 106 (53\%). Adolescents with unsupportive and supportive subjective norms had the same number, namely 100 (50\%). Adolescents who had weak peer support were 92 (46\%), while adolescents with strong peer support were 108 (54\%). Adolescents with stronger family intimacy were 89 (44.5\%) less than tee- nagers who had weak family intimacy, as much as 111 (55.5\%). Adolescents with weak self-efficacy (for not doing) were 99 (49.5\%), while adolescents with strong selfefficacy (for not doing) were 101 (50.5\%). Teenagers who had premarital sex were 98 (49\%), while teens who did not have premarital sex were 102 (51\%).

\section{Bivariate Analysis}

The bivariate analysis used the chi-square test. Bivariate analysis based on the results of this study can be seen in Table 4 .

Table 4 Bivariate Analysis of Determinants of Premarital Sex Behavior

\begin{tabular}{|c|c|c|c|c|c|c|c|c|}
\hline \multirow{3}{*}{$\begin{array}{c}\text { Independent } \\
\text { Variable }\end{array}$} & \multicolumn{4}{|c|}{$\begin{array}{c}\text { Premarital Sex } \\
\text { Behavior }\end{array}$} & \multirow{2}{*}{\multicolumn{2}{|c|}{ Total }} & \multirow{3}{*}{ OR } & \multirow{3}{*}{$\mathbf{p}$} \\
\hline & \multicolumn{2}{|c|}{ No } & \multicolumn{2}{|c|}{ Yes } & & & & \\
\hline & $\mathbf{N}$ & $\%$ & $\mathbf{N}$ & $\%$ & $\mathbf{N}$ & $\%$ & & \\
\hline \multicolumn{9}{|l|}{ Intention } \\
\hline Weak & 74 & 74.75 & 25 & 25.25 & 99 & 100 & \multirow[t]{2}{*}{9.49} & \multirow[t]{3}{*}{$<0.001$} \\
\hline Strong & 24 & 23.76 & 77 & 76.24 & 101 & 100 & & \\
\hline \multicolumn{8}{|l|}{ Attitude } & \\
\hline Negative & 76 & 80.85 & 18 & 19.15 & 94 & 100 & \multirow[t]{3}{*}{16.1} & \multirow[t]{2}{*}{$<0.001$} \\
\hline Positive & 22 & $17 \cdot 3$ & 84 & 79.25 & 106 & 100 & & \\
\hline \multicolumn{8}{|l|}{ Subjective norms } & \\
\hline Unsupportive & 77 & 77.00 & 23 & 23.00 & 100 & 100 & \multirow[t]{2}{*}{12.5} & \multirow[t]{2}{*}{$<0.001$} \\
\hline Support & 21 & 21.00 & 79 & 79.00 & 100 & 100 & & \\
\hline \multicolumn{9}{|l|}{ Peers } \\
\hline Weak & 67 & 72.83 & 25 & 27.17 & 92 & 100 & \multirow[t]{2}{*}{6.65} & \multirow[t]{2}{*}{$<0.001$} \\
\hline Strong & 31 & 28.70 & 77 & 71.30 & 108 & 100 & & \\
\hline \multicolumn{9}{|l|}{ Family intimacy } \\
\hline Weak & 28 & 25.23 & 83 & 74.77 & 111 & 100 & \multirow[t]{3}{*}{0.09} & \multirow[t]{2}{*}{$<0.001$} \\
\hline Strong & 70 & 78.65 & 19 & 21.35 & 89 & 100 & & \\
\hline \multicolumn{8}{|l|}{ Self-efficacy } & \\
\hline Weak & 23 & 23.23 & 76 & 76.77 & 99 & 100 & \multirow[t]{2}{*}{0.10} & \multirow[t]{2}{*}{$<0.001$} \\
\hline Strong & 75 & 74.26 & 26 & 25.74 & 101 & 100 & & \\
\hline
\end{tabular}

Table 4 shows the results of the chi-square test of the effect between premarital sex behavior with intention, attitude, subjective norms, peer support, family intimacy, and self-efficacy, namely:

a. Adolescents with strong intentions (76.24\%) were more likely to have a higher percentage of premarital sexual behavior than weak intentions (25.25\%), and the difference was statistically significant $(\mathrm{p}<0.001)$. b. Adolescents with positive attitudes (79.25\%) were more likely to have higher percentages of premarital sex behavior than negative attitudes (19.15\%) and the difference was statistically significant ( $p$ $<0.001)$.

c. Adolescents with supportive norms (79.00\%) were more likely to have a higher percentage of premarital sex behavior than non-supportive norms 
(23.00\%) and the difference was statistically significant $(\mathrm{p}<0.001)$.

d. Adolescents with strong peer support (71.30\%) were more likely to have a higher percentage of premarital sexual behavior than weak peer support (27.17\%) and the difference was statistically significant $(\mathrm{p}<0.001)$.

e. Adolescents with weak family intimacy (74.77\%) were more likely to have a higher percentage of premarital sex behavior than strong family intimacy (21.35\%).

f. Adolescents with weak self-efficacy (76.77\%) were more likely to have a higher percentage of premarital sex behavior than strong self-efficacy (25.74\%) and the difference was statistically significant $(\mathrm{p}<0.001)$.

\section{Multivariate Analysis}

Multilevel analysis explained the effect of more than one independent variable (intention, attitude, subjective norms, peer support, family intimacy, and self-efficacy) with the dependent variable (premarital sex behavior). The multivariate analysis results used multiple logistic regression with a multilevel approach can be seen in Table 4 .

Table 5. Multilevel Multiple Logistic Regression Analysis of Premarital Sex Behavior

\begin{tabular}{|c|c|c|c|c|}
\hline \multirow{2}{*}{ Independent variable } & \multirow[b]{2}{*}{ b } & \multicolumn{2}{|c|}{ CI 95\% } & \multirow[b]{2}{*}{$\mathbf{p}$} \\
\hline & & $\begin{array}{c}\text { Lower } \\
\text { limit }\end{array}$ & $\begin{array}{c}\text { Upper } \\
\text { limit }\end{array}$ & \\
\hline \multicolumn{5}{|l|}{ Fixed effect } \\
\hline Intention (strong) & 1.23 & 0.12 & 2.34 & 0.029 \\
\hline Attitude (positive) & 1.25 & 0.14 & 2.36 & 0.027 \\
\hline Norm (support) & 1.11 & 0.05 & 2.16 & 0.039 \\
\hline Peer support (strong) & 1.46 & 0.40 & 2.45 & 0.007 \\
\hline Family intimacy (strong) & -1.59 & -2.74 & -0.45 & 0.006 \\
\hline Self-efficacy (strong) & -1.07 & -2.10 & -0.49 & 0.040 \\
\hline \multicolumn{5}{|l|}{ Random effect } \\
\hline School & & & & \\
\hline Var (Constanta) & 1.07 & 0.21 & 0.86 & \\
\hline \multicolumn{5}{|l|}{$\mathrm{N}$ observation $=200$} \\
\hline \multicolumn{5}{|l|}{$\mathrm{N}$ group $=25$} \\
\hline \multicolumn{5}{|l|}{ Group average $=8, \min =8, \max =8$} \\
\hline Log likelihood $=-67.20 p=0.023$ & & & & \\
\hline $\mathrm{ICC}=24.6 \%$ & & & & \\
\hline
\end{tabular}

Table 5 multilevel multiple logistic regression results can be explained as follows:

\section{a. The effect of intention on prema- rital sex behavior in adolescents}

The results of the multilevel logistic regression analysis showed that there was a correlation between intention and premarital sex behavior among adolescents. Table 5 can show that there was a positive and statistically significant correlation. Adolescents with strong intentions had a logodd likelihood of having premarital sex behavior 1.23

units greater than adolescents with weak intentions $(\mathrm{b}=1.23 ; 95 \% \mathrm{CI}=0.12$ to 2.34 ; $\mathrm{p}=0.029$ ).

b. The effect of attitudes on premarital sex behavior in adolescents

There was an effect between the attitudes and behavior of premarital sex in adolescents. Adolescents with positive attitudes 
had a logodd (probability) to engage in premarital sex behavior by 1.22 units higher than adolescents with negative attitudes $(b=1.25 ; 95 \% \mathrm{CI}=0.14$ to $2.36 ; \mathrm{p}=0.027)$.

\section{c. The effect of norms on premarital sex behavior in adolescents}

There was an effect between norms and premarital sex behavior in adolescents. Adolescents with supportive norms had a logodd (probability) to engage in premarital sex behavior by 1.11 units higher than adolescents with unsupportive norms $(b=1.11$; $95 \% \mathrm{CI}=0.05$ to $2.16 ; \mathrm{p}=0.39$ ).

\section{d. The effect of peers on premarital} sex behavior in adolescents

There was an effect between peers and premarital sex behavior in adolescents. Adolescents with strong peer support had a logodd (likelihood) of engaging in premarital sex behavior by 1.46 units higher than adolescents with weak peer support $(b=1.46 ; 95 \%$ $\mathrm{CI}=0.40$ to $2.45 ; \mathrm{p}=0.007$ ).

e. The effect of family intimacy on premarital sex behavior in adolescents

There was an effect between family intimacy and premarital sex behavior in adolescents. Adolescents with strong family intimacy had a logodd (likelihood) of engaging in premarital sex behavior by -1.59 units lower than adolescents with non-weak family intimacy $(b=-1.59 ; 95 \% \mathrm{CI}=-2.74$ to $-0.45 ; \mathrm{p}=0.006)$.

\section{f. The effect of self-efficacy for abs- tinence on premarital sex behavior in adolescents}

There was an effect between self-efficacy for abstinence and premarital sex behavior in adolescents. Adolescents with strong selfefficacy for abstinence had a logodd (likelihood) of engaging in premarital sex behavior by -1.03 units lower than adolescents with weak self-efficacy $(b=-1.07 ; 95 \% \mathrm{CI}=$ -2.10 to $-0.49 ; \mathrm{p}=0.040$ ).

\section{g. The effect of school context on patient satisfaction}

The ICC results of $24.6 \%$ indicated that each school stratum had a contextual effect on variations in premarital sex behavior by $24.6 \%$. This figure was greater than the role of thumb $8-10 \%$, so the school contextual effect that was shown from the multilevel analysis was very important to note.

\section{DISCUSSION
1. The effect of intention on prema- rital sex behavior in adolescents}

The results of this study indicated that intention affected premarital sex behavior in adolescents. Based on table 4 it can be interpreted that there was a positive and statistically significant correlation. Adolescents with strong intentions had log odds of having premarital sex behavior 1.06 units greater than adolescents with weak intentions $(\mathrm{b}=1.23 ; 95 \% \mathrm{CI}=0.12$ to $2.34 ; \mathrm{p}=$ 0.029).

This study's results are in line with a study conducted by Shek (2013) in Hong Kong, which found that the intention to engage in sexual behavior was one of the risk factors for sexual behavior in adolescents. Adolescents who have the intention to engage in sexual behavior will have the possibility to engage in sexual behavior in the future. The intention to engage in sexual behavior is related to the actual sexual behavior of adolescents.

Another study conducted by Morales et al. (2018) on Colombian adolescents stated that intention was a predictor during sexual intercourse. Other findings suggest that adolescent sexual behavior and intentions engage in sexual behavior gradually increase over time. Sexual behavior and the intention to engage in sexual behavior will gradually increase from year to year in junior high school. Older adolescents have higher sexual behavior intentions than 
younger adolescents (Shek and Leung, 2016).

2. The effect of attitudes on premarital sex behavior in adolescents

The results of this study indicated that there was a correlation between premarital sex attitudes and behavior in adolescents. Adolescents with positive attitudes had a logodd (probability) to have premarital sex behavior by 1.25 units higher than adolescents with negative attitudes $(b=1.25 ; 95 \%$ $\mathrm{CI}=0.14$ to $2.36 ; \mathrm{p}=0.027$ ).

Adolescent attitudes, normative beliefs, and adolescent self-efficacy were related to engaging in sexual activity, respectively. In particular, adolescents who have a more positive attitude about sexual activity were more likely to intend to engage in sexual activity and even have sex. Adolescent attitudes and beliefs are also important predictors of sexual activity. They may be more influential than other factors (Scull et al. 2018). It is similar to a study conducted by Yip et al. (2013), which stated that on unmarried adolescents, there were more than half of Hong Kong youth who were not married showed a liberal attitude towards premarital sex. All types of sexual behavior were the main factors related to adolescents sexual behavior.

Motamedi et al. (2016) also argued that adolescents' attitude from year to year was more liberal towards premarital sex compared to before 2000. Openness showed a greater degree of premarital sex behavior, including sexual relations. Ghaffari et al. (2016) found that some students said they had a positive attitude toward having sex. Some of them believe that premarital sexual relations are necessary. Positive adolescent attitudes towards premarital sexual behavior can pose a risk of unwanted pregnancy and contracting STIs. The higher the positive attitude towards premarital sex behavior, the more likely adolescents will engage in premarital sex behavior until they have sex.

\section{The effect of norms on premarital sex behavior in adolescents}

There was an effect between norms and premarital sex behavior in adolescents. Adolescents with supportive norms had a logodd (probability) to engage in premarital sex behavior by 1.11 units higher than adolescents with unsupportive norms $(b=1.11$; 95\% $\mathrm{CI}=0.05$ to $2.16 ; \mathrm{p}=0.039$ ).

Certain community norms and demographics suggest that premarital sex is likely to become increasingly common among teenagers. (Gibbs et al. 2014). Those who have positive (supportive) norms towards premarital sex state that their friends have premarital sex. This is very common and common in their society. Positive norms of premarital sex increase the risk of early premarital sexual acts. Social norms influence adolescent sexual behavior (Thin Zaw et al. 2013).

Subjective norms are formed after individuals have normative beliefs, namely the extent to which individuals are willing to engage in premarital sex behavior based on their environment. For example, suppose the individual is in an environment with a lot of premarital sex behavior. In that case, the individual will tend to display premarital sex behavior. If the individual's environment does not support premarital sex behavior, he will not do it. A person considers other people's opinions about premarital sexual behavior and will be motivated or not to do this action according to what the people closest to him want (Rosenbaum and Weathersbee, 2013).

\section{The effect of peers on premarital sex behavior in adolescents}

There was an effect between peers and premarital sex behavior in adolescents. Adolescents with strong peer support had a logodd (likelihood) of engaging in premarital sex 
behavior by 1.46 units higher than adolescents with weak peer support $(b=1.46 ; 95 \%$ $\mathrm{CI}=0.40$ to $2.45 ; \mathrm{p}=0.007$ ).

A study conducted by Ghaffari et al. (2016) provided results regarding sexual behavior in that there were students who stated that their friends think premarital sex behavior is common and when these students talk with them about sexual relations.

SCT suggests that engagement in new behaviors is promoted by observing valued social reference behaviors, such as peers. This process is known as role modeling, imitation or observation learning. The greater the number of peers involved in a particular behavior, the more functional and correct the behavior will be. The more likely the adolescent will engage in the same behavior. Peers have an important role in adolescent sexual development.

Adolescents who consider their peers more sexually active, more agreeable to sexual behavior, and more pressure on them to be sexually active tend to be more sexually active. Likewise, adolescents who believe that their peers engage in more risky sexual behavior tend to engage in that behavior. Observing peers who engage in certain behaviors has more impact on adolescent decisions to engage in similar behavior (van de Bongardt et al. 2015).

\section{The effect of family intimacy on premarital sex behavior in adoles- cents}

There was an effect between family intimacy and premarital sex behavior in adolescents. Adolescents with strong family intimacy had a logodd (likelihood) of engaging in premarital sex behavior by -1.59 units lower than adolescents with non-weak family intimacy $(b=-1.59 ; 95 \% \mathrm{CI}=-2.74$ to -0.45; $\mathrm{p}=0.006$.

Alhassan and Dodoo (2020) found that sexual communication between family members was very important to prevent premarital sexual behavior. They emphasized the importance of communicating with teenagers about things that might even be considered sensitive (taboo). Open communication about sex, especially with parents, is an effective way to prevent sexual behavior among unmarried adolescents. When parents openly discuss sexual issues with their children, teens are more likely not to behave sexually. Sexual communication with both parents is the maximum support for adolescents not to have premarital sexual behavior. Discussing sexual matters with both parents can also provide adolescents with adequate information about sex, pregnancy, STIs.

Communication between parents and adolescents is strong (often) about sexual behavior can reduce premarital sex behavior. The results in this sample of unmarried adolescents suggest that with each unit score increase in communication between parents and adolescents can reduce the risk of adolescents engaging in risky sexual behavior by 20\%. Teens who have strong family intimacy are less likely to initiate sexual activity. Parents are the first agents of socialization for their children. Parents are a source of knowledge, beliefs, attitudes, and values for children and adolescents. These values tend to shape adolescent behavior, which can be transmitted from parents to children directly or indirectly through a process of communication and action with their children (Munea et al. 2020).

A study conducted by Shek (2013) on adolescents in 28 secondary schools in Hong Kong found that family functioning and good adolescent development are important protective factors to prevent premarital sex behavior in adolescents and engage in sexual behavior. 


\section{The effect of self-efficacy for abs- tinence on premarital sex behavior in adolescents}

There was an effect between self-efficacy for abstinence and premarital sex behavior in adolescents. Adolescents with strong selfefficacy for not doing so had a logodd (likelihood) of engaging in premarital sex behavior by -1.07 units lower than adolescents with weak self-efficacy $(b=-1.07 ; 95 \% \mathrm{CI}=$ -2.10 to $-0.49 ; \mathrm{p}=0.040$ ).

Self-efficacy is a person's confidence in his ability to do or not do something behavior. Self-efficacy is developed through personal experience, social learning, and social persuasion. Ghaffari et al. (2016) stated that students who have high self-efficacy can control themselves against sexual stimulation and avoid premarital sexual behavior.

Self-efficacy is a self-referential assessment of how well a person can control their behavior. Self-efficacy, in particular, can reduce premarital sex behavior. A study conducted by Boone et al. (2015) states that someone who has higher self-efficacy is also more knowledgeable about sexual health and behavior, thereby reducing premarital sexual behavior. Religion and religiosity of a person have a strong positive effect in increasing self-efficacy. A person who believes in sexual abstinence and prohibits contraceptives will avoid not engaging in premarital sexual behavior (Ajayi and Olamijuwon, 2019).

\section{The effect of school context on pre-} marital sex behavior in adolescents

Schools are a place to promote reproductive health to prevent sexual behavior and premature sexual intercourse. Studying in school reduces the amount of free time adolescents have and improves education to prepare youth career needs, and empowers adolescents with the necessary skills to reduce premarital sexual behavior. This im- plies that increasing school participation can be an effective strategy to promote accurate information to students about reproductive health issues such as awareness of fertility, sexual relations, pregnancy, and STIs (Alhassan and Dodoo, 2020).

Better education is a protective factor for risky sexual behavior as well as premarital sex, suggesting that the school environment may provide a context in which early sexual activity is discouraged (Yip et al. 2013).

The systematic review and meta-analysis study conducted by Sani et al. (2016) stated that interventions to protect adolescents from sexual behavior and STIs can be inclusive and provide comprehensive preventive education and training. School-based sexual health education may be an effective strategy for promoting reproductive health. There are still many schools that have not provided educational education related to reproductive health. This is shown by many adolescents who have insufficient knowledge about reproductive health and the impact of premarital sexual behavior.

\section{AUTHOR CONTRIBUTION}

As the main researcher, Nur Laili Qomariah played a role in coordinating the study, conducting all study stages, and completing the paper. Eti Poncorini Pamungkasari had a role in developing ideas, study designs, and research hypotheses. Uki Retno Budihastuti played a role in compiling the research framework, processing research data, representing the research analysis results, and preparing research papers.

\section{CONFLICT OF INTEREST}

There was no conflict of interest whatsoever in this study.

\section{FUNDING AND SPONSORSHIP}


This study used the main researcher's funds.

\section{ACKNOWLEDGEMENT}

The authors would like to express their grat goes to all Principals of Gresik Regency who had allowed this study to be carried out and to students who participated and were willing to be respondents in the research.

\section{REFERENCE}

Ajayi AI and Olamijuwon EO (2019). What predicts self-efficacy? Understanding the role of sociodemographic, behavioural and parental factors on condom use self-efficacy among university students in Nigeria. a. PLoS ONE 14(8):e0221804 https://doi.or$\mathrm{g} / 101371 /$ journal.pone.0221804.

Ajzen I (2011). The theory of planned behaviour: reactions and reflections. Psychology and Health, 26(9), 11131127. https://doi.org/10.1080/o8870446.2011.613995.

Alhassan N dan Dodoo FNA (2020). Predictors of primary and secondary sexual abstinence among nevermarried youth in urban poor Accra, Ghana. Reprod. Health 17(28) https://doi.org/10.1186/s12978-020-o885-4.

Boone MR, Cherenack EM, Wilson PA (2015). Self-Efficacy for Sexual Risk Reduction and Partner HIV Status as Correlates of Sexual Risk Behavior Among HIV-Positive Adolescent Girls and Women. AIDS Patient Care STDS, 29(6): 346-353. https://doi.org/10.1089/apc.2014.0175.

Ghaffari M, Gharghani ZG, Mehrabi Y, Ramezankhani A, Movahed $\mathrm{M}$. (2016). Premarital sexual intercourse-related individual factors among Iranian adolescents: A qualitative study. Iran Red Crescent Med
J, 18(2): 21220. https://doi.org/10.$5812 /$ ircmj. 21220.

Gibbs SE, Le LC, Dao HB, Blum RW (2014). Peer and community influences on the acceptance of premarital sex among Vietnamese adolescents. J Paediatr Child Health, 50(6): 438443.https://doi.org/10.1111/jpc.12512.

Kementerian Kesehatan RI (2018). Laporan hasil riset kesehatan dasar (riskesdas) Indonesia tahun 2018. riset kesehatan dasar 2018: 182-183. Retrieved from https://www.kemkes.go.id/resources/download/infoterkini/hasil-riskesdas-2018.pdf

Margaretha (2012). Psikologi forensik dan psikopatologi dan perilaku berisiko remaja. Retrieved from https://psikologiforensik.com/2012/o3/o2/perilakuberesiko-remaja-seks-adiksidan-hiv/.

Morales A, Vallejo-Medina P, Abello-Luque D, Saavedra-Roa A, García-Roncallo P, Gomez-Lugo M, García-Montaño E, et. al., (2018). Sexual risk among Colombian adolescents: Knowledge, attitudes, normative beliefs, perceived control, intention, and sexual behavior. BMC Public Health, 18(1): 1377. https://doi.org/10.1186/s12889-018-6311-y.

Motamedi M, Merghati-Khoei E, Shahbazi M, Rahimi-Naghani S, Salehi M, Karimi M, Hajebi A, et. al., (2016). Paradoxical attitudes toward premarital dating and sexual encounters in Tehran, Iran: A cross-sectional study. Reprod. Health, 13(1). https://doi.org/10.1186/s12978-016-0210-4. Munea AM, Alene GD, Debelew GT (2020). Does youth-friendly service intervention reduce risky sexual behavior in unmarried adolescents? A comparative study in west Gojjam zone, 
northwest Ethiopia. Risk Manag. Healthc. Policy, 13(1): 941-954. https://doi.org/10.2147/RMHP.S2546885.

Rosenbaum JE, Weathersbee B (2013). True Love Waits: Do Southern Baptists? Premarital Sexual Behavior Among Newly Married Southern Baptist Sunday School Students. J Relig Health, 52(1): 263-275. https://doi.org/10.1007/s10943-0109445-5.

Sani, AS, Abraham C, Denford S, Ball S (2016). School-based sexual health education interventions to prevent STI/HIV in sub-Saharan Africa: a systematic review and meta-analysis. BMC Public Health, 16(1): 126.https://doi.org/10.1186/s12889016-3715-4.

Scull TM, Malik CV, Kupersmidt JB (2018). Understanding the unique role of media message processing in predicting adolescent sexual behavior intentions in the USA. J Child Media 12(3): 258-274. https://doi.org/10.1080/17482798.2017.1403937.

Shek DTL (2013). Sexual behavior and intention to engage in sexual behavior in junior secondary school students in Hong Kong. $\mathrm{J}$ Pediatr Adolesc Gynecol, 26(3 SUPPL): S33-S41. https://doi.org/10.1016/j.jpag.2013.03.013.
Shek DTL dan Leung H (2016). Do Adolescent Sexual Behavior and Intention to Engage in Sexual Behavior Change in High School Years in HongKong?. J Pediatr Adolesc Gynecol, 29(1): S49-S6o https://doi.org/10.1016/j.jpag.2015.10.008.

Thin Zaw PP, Liabsuetrakul T, McNeil E, Htay TT (2013). Gender differences in exposure to SRH information and risky sexual debut among poor Myanmar youths. BMC Public Health, 13(1): 1122. https://doi.org/10.1186/1471-2458-13-1122.

Van de Bongardt D, Reitz E, Sandfort T, Deković M (2015). A Meta-Analysis of the Relations Between Three Types of Peer Norms and Adolescent Sexual Behavior. Pers. Soc. Psychol. Rev. 19(3): 203-234. https://doi.org/10.1177/1088868314544223.

Yip PS, Zhang H, Lam TH, Lam KF, Lee AM, Chan J, Fan S (2013). Sex knowledge, attitudes, and high-risk sexual behaviors among unmarried youth in Hong Kong. BMC Public Health, 13(1): 691. https://doi.org/10.1186/1471-2458-13-69.

WHO (2018). Adolescents: health risks and solutions Retrieved from https://www.who.int/news-room/fact-sheets/detail/adolescents-health-risks-and-solutions. 